\title{
The spiny rat Proechimys guyannensis (Rodentia: Echimydae) fails to respond to intradermal inoculation with Leishmania (Viannia) braziliensis
}

\author{
Stela Rechinelli PASSOS ${ }^{1}$, Ana Paula MADUREIRA², Sayanne Luns Hatum de ALMEIDA ${ }^{1}$, \\ Marcos Santos ZANINI ${ }^{1^{*}}$ \\ 1 Universidade Federal do Espírito Santo, Departamento de Medicina Veterinária, Alto Universitário s/n, 29500-000, Alegre, Espírito Santo, Brazil \\ 2 Universidade Federal de São João del-Rei, Departamento de Engenharia de Biossistemas, Praça Dom Helvécio, 74 - Campus Dom Bosco, $36301-160$, São João del Rei, Minas \\ Gerais, Brazil. \\ * Corresponding author: marcos.zanini@ufes.br
}

\section{ABSTRACT}

Leishmaniasis a disease of worldwide occurrence is caused by protozoa of the Leishmania genus. In Brazil, Leishmania (Viannia) braziliensis is the main parasite responsible for the American cutaneous leishmaniasis. Main hosts of this protozoa are small wild mammals particularly marsupials and rodents. The aim of this study was to evaluate if spiny rat Proechimys guyannensis (Rodentia: Echimydae) has role in the cycle of the American cutaneous leishmaniasis caused by L. (V.) braziliensis. Thus, promastigotes (the flagellate stage) of Leishmania (Viannia) braziliensis were used to inoculate seven spiny rats (Proechimys guyannensis). After inoculated intradermal at the ear pinna, nose and plantar pad, the rats were monitored for 180 days. Tissue samples collected at 90 and 180 days from the rats proved to be negative for the presence of genetic material from the parasite. After euthanasia, the protozoa also failed to growth in culture medium containing tissue samples collected from the rats showing that there was no infection. These results fail to prove that spiny rat has a role in the cycle of the American cutaneous leishmaniasis caused by $L$. (V.) braziliensis.

KEYWORDS: Leishmaniasis, American cutaneous leishmaniasis, rodents, reservoirs

\section{O rato espinhoso Proechimys guyannensis (Rodentia: Echimydae) falhou para inoculação intradérmica com Leishmania (Viannia) braziliensis.}

\section{RESUMO}

A leishmaniose é uma doença de ocorrência mundial causada por protozoários do gênero Leishmania. No Brasil, a Leishmania (Viannia) braziliensis é o principal parasita responsável pela leishmaniose tegumentar americana. Os principais hospedeiros deste protozoário são pequenos mamíferos selvagens em particular marsupiais e roedores. O objetivo deste estudo foi avaliar o papel do rato espinhoso Proechimys guyannensis (Rodentia: Echimydae) no ciclo da leishmaniose tegumentar americana. Para isto, formas promastigotas (estágio flagelado) de Leishmania (Viannia) braziliensis foram inoculadas em sete ratos espinhosos (Proechimys guyannensis). Após a inoculação intradérmica no pavilhão auricular, focinho e área plantar, os ratos foram monitorizados durante 180 dias. Amostras de tecido colhidas aos 90 e 180 dias dos ratos revelaram-se negativas para a presença de material genético do parasita. Após eutanásia, tecidos coletados dos ratos também falharam para crescimento em meio de cultura demonstrando que não houve infecção. Estes resultados demonstram que o rato espinhoso não tem papel no ciclo da leishmaniose tegumentar americana causada por L. (V.) braziliensis.

PALAVRAS-CHAVE: Leishmaniose, leishmaniose tegumentar americana, roedores, reservatórios. 
Leishmaniasis is a disease of worldwide occurrence, caused by protozoa of the Leishmania genus. In Brazil, Leishmania (Viannia) braziliensis is the main causative agent of American Cutaneous Leishmaniasis - ACL (Roque et al. 2010). Leishmania genus exist in two basic body forms: the amastigote, the intracellular form in the vertebrate host, and the promastigote, the extracellular form in the sandfly (Phleobotomus spp. and Lutzomyia spp.) vector or culture medium. The main hosts of this agent are small wild mammals, especially rodents and marsupials. Spiny rats from the genus Proechimys are among the most abundant Amazonian rodents (Eler et al. 2012). These rodents have attracted interest in the area of biology and epidemiology of viral and tropical zoonotic diseases because they are often found as hosts of protozoa of the genus Trypanosoma and viruses (Carrara et al. 2005; Rosa et al. 2005; Pinto et al. 2006). These rodents are also reported as being reservoirs of $L$. (L.) amazonensis in the Amazon region (Brandão-Filho et al. 2003) and studies indicate their potential to act as a host of other species causative of skin disease, such as L. (V.) panamensis (Travi et al. 2002). Didelphis marsupialis and Proechimys canicollis are wild mammals with impact on transmission of $L$. chagasi in northern Colombia (Adler et al. 2003; Lainson et al. 2002). The aim of this study was to evaluate if spiny rat Proechimys guyannensis (Rodentia: Echimydae) has role in the cycle of the American cutaneous leishmaniasis caused by L. (V.) braziliensis.

Fourteen adults males of Proechimys guyannensis (10-12 weeks old, 170-180 grams) born in captivity of the Federal University of São João del Rei and as positive control for infection six outbred golden hamsters (Mesocricetus auratus), adult males (8-10 weeks old), weighing 90-100 grams (Gomes-Silva et al. 2013) were used. The protocols employed for the collection of biological samples for the study of the Proechimys guyannensis followed those approved by the ICMBio/SISBIO no24065 - Ministry of the Environment and Ethics Committee for Animal Experimentation under protocol 017/2010 (CEUA- UFES) registered in the National Animal Control Experimentation (CONCEA, Brazil). The animals were housed in pairs in polycarbonate cages of $41 \times 34 \times 17 \mathrm{~cm}$ and under natural conditions. Water and food were provided ad libitum. The feed used was Nuvilab CR1 mouse pellets (Nuvital nutrients SA, Colombo / PR, Brazil), and as bedding sawdust was utilized. The Proechimys guyannensis was divided into two groups ( $\mathrm{n}=7)$; intradermally inoculation with promastigotes of $L$. (V.) braziliensis from of canine lesions for Group 1 and promastigotes standard strain of $L$. (V.) braziliensis (MHOM/BR/75/M2903) for Group 2. The golden hamsters were also divided into two groups of three animals and inoculated with the different $L$. (V.) braziliensis strains. The promastigotes of Group 1 were obtained from an infected $\operatorname{dog}$ lesion. The infection of the dog with $L$. (V.) braziliensis was confirmed by culture, polymerase chain reac- tion (PCR) using primers B1 e B2 (De Bruijn and Barker 1992) and Western Blot (Zanini et al. 2010) of a collected fragment from the injured tissue. For sample collection, the dogs were sedated with xylazine $\left(2.2 \mathrm{mg} \mathrm{kg}^{-1}\right)$ and ketamine $\left(10 \mathrm{mg} \mathrm{kg}^{-1}\right)$ in association. A fragment of $1 \mathrm{~cm}^{2}$ was collected from the lesion edge. The fragment was divided into two parts - one for performing the PCR, and the other for culture in NNN-LIT (Novy MacNeal Nicolle - Liver Infusion Tryptose) medium, increased $10 \%$ Fetal Bovine Serum, which served as a source of promastigotes and culture for the parasite. In their stationary growth phase the two strains (dog strain and standard strain) were then washed in phosphate-buffered saline, $0.15 \mathrm{M}, \mathrm{pH} 7.2$ and adjusted for promastigotes count of $1 \times 10^{6} \mathrm{~mL}^{-1}$. The count of promastigotes standard strain and of that isolated from the dog was performed with Neubauer hemocytometer $\left(1 \times 10^{6} \mathrm{~mL}^{-1}\right)$ and $0.05 \mathrm{~mL}$ of promastigotes were inoculated intradermally at the right ear pinna, nose and right plantar pad in Proechimys. The golden hamsters were inoculated intradermally only at the right plantar pad with $0.05 \mathrm{~mL}$ of the suspension $1 \times 10^{6} \mathrm{~mL}^{-1}$ of promastigotes in the stationary growth phase. During inoculation the rodents were sedated with xylazine ( $\left.4.4 \mathrm{mg} \mathrm{kg}^{-1} \mathrm{IM}\right)$ and ketamine (72 $\mathrm{mg} \mathrm{kg}^{-1} \mathrm{IM}$ ) in association. The volume of inoculum used and the concentration of the parasite was used according Roque et al. (2010).

After 90 and 180 days, tissue fragments were collected at the site of inoculation. The monitoring of the infected animals was performed for 180 days using PCR and the culture of tissue fragments collected from the site of inoculation, and observation of the development of lesions. From these fragments PCR and culture of microorganisms were performed, using a methodology similar to previously mentioned. For tissues of $P$. guyannensis collected at 90 and 180 days the presence of genetic material of the parasite inoculated were not observed according to PCR assessment or growth in NNN-LIT culture medium. Dissemination of parasites to spleen and other peripheral lymph nodes beyond the inoculation site were evaluated after euthanasia of $P$. guyannensis at 180 days and the result was negative to PCR analysis showing that there was no infection. However all hamsters after 100 days already showed cutaneous ulcerated lesions with elevated erythematous borders or necrotic surface recovered by crusts and culture isolation of $L$. $(V$.) braziliensis. In other experimental inoculation (data not shown) the isolation of $L$. braziliensis was obtained from two $P$. guyannensis only when intra peritoneal inoculation of the parasite followed by culture of spleen tissue fragments in NNN-LIT was performed although this is not a natural way of infection. As observed, concerning visceral leishmaniasis (Lainson et al. 2002), this rodent has not shown itself capable of amplifying the population of $L$. (V.) braziliensis in the skin nor did it allow the isolation of the parasite in 
its tissues during the 180 days of monitoring post-infection. Although other authors believe that most rodents are the primary reservoirs of $L$. (V.) braziliensis (Brandão-Filho et al. 2003) and particularly the golden hamster, the latter is therefore an appropriate model for immunopathogenesis studies of CL caused by L. braziliensis (Gomes-Silva et al. 2013). In experimental inoculation the putative role of rodent Thrichomys laurentius in the retention of infection and amplification of the transmission cycle of Leishmania infantum and L. braziliensis (Roque et al. 2010) was observed. Also the Proechimys semispinosus has been experimentally observed and indicated as a reservoir of Leishmania (Viannia) panamensis on the Colombian Pacific coast. While most of the findings of $L$. (V.) braziliensis infection under natural conditions were in Rattus rattus (Lima et al. 2013), Thrichomys apereoides and Didelphis albiventris (Quaresma et al. 2011) were indicated as natural reservoirs of $L$. (V.) braziliensis. Even though as yet there is no evidence in the literature for the verification of any reported natural infection of $P$. guyannensis by $L$. braziliensis.

The factors like the immunomodulatory properties in the saliva of the insect vector have been studied for vaccine production and may affect the results obtained in experimental infection (Kamhawi 2000; Oliveira et al. 2013) but other authors also report success in experimental infection without use of saliva (Gomes-Silva et al. 2013; Roque et al. 2010). Thus, it seems that P. guyannensis does not have an active role in the transmission cycle of ACL caused by $L$. (V.) braziliensis once isolating the parasite or its genome from the inoculated animals has failed.

\section{ACKNOWLEDGMENTS}

This research was supported by grants Fundação de Amparo à Pesquisa do Estado do Espírito Santo, ES, Brazil and Universidade Federal de São João del Rei, São del ReiMG, Brazil.

\section{REFERENCES}

Adler, G.H.; Becerra, M.T.; Travi, B.L. 2003. Feeding success of Lutzomyia evansi (Diptera: Psychodidae) experimentally exposed to small mammal hosts in an endemic focus of Leishmania chagasi in northern Colombia. Biomedica, 23:396-400.

Brandão-Filho, S.P.; Brito, M.E.; Carvalho, F.G.; Ishikawa, E.A.; Cupolillo, E.; Floeter-Winter, L.; Shaw, J.J. 2003. Wild and synanthropic hosts of Leishmania (Viannia) braziliensis in the endemic cutaneous leishmaniasis locality of Amaraji, Pernambuco State, Brazil. Transactions of the Royal Society of Tropical Medicine and Hygiene, 97: 291-296.

Carrara, A.S.; Gonzales, G.; Ferro, C.; Tamayo, M.; Aronson, J.; Paessler, S.; et al. 2005. Venezuelan equine encephalitis virus infection of spiny rats. Emerging Infectious Disease, 11: 663-669.

De Bruijn M.H.; Barker D.C. 1992. Diagnosis of New World leishmaniasis: specific detection of species of the Leishmania braziliensis complex by amplification of kinetoplast DNA. Acta Tropica, 52: 45-58.

Eler, E.S.; da Silva, M.N.; Silva, C.E.; Feldberg, E. 2012. Comparative cytogenetics of spiny rats of the genus Proechimys (Rodentia, Echimyidae) from the Amazon region. Genetics and Molecular Research, 11: 830-46.

Gomes-Silva A.; Valverde, J.G.; Ribeiro-Romão, R.P.; Plácido-Pereira, R.M.; da Cruz, A.M. 2013. Golden hamster (Mesocricetus auratus) as an experimental model for Leishmania (Viannia) braziliensis infection. Parasitology, 140:771-9.

Lainson, R.; Ishikawa, E.A.Y.; Silveira, F.T. 2002. American visceral leishmaniasis: wild animal hosts. Transactions of the Royal Society of Tropical Medicine and Hygiene, 96: 630-631.

Lima, B.S.; Dantas-Torres, F.; de Carvalho, M.R.; Marinho-Junior, J.F.; de Almeida, E.L.; Brito, M.E. et al. 2013. Small mammals as hosts of Leishmania spp. In a highly endemic area for zoonotic leishmaniasis in North-Eastern Brazil. Transactions of the Royal Society of Tropical Medicine and Hygiene, 107: 592-597.

Kamhawi, S. 2000. The biological and immunomodulatory properties of sand fly saliva and its role in the establishment of Leishmania infections. Microbes Infection, 2: 1765-1773.

Oliveira, F.; de Carvalho, A.M.; de Oliveira, C.I. 2013. Sand-fly saliva-leishmania-man: the trigger trio. Frontiers in Immunology, 4: 375; doi: 10.3389/fimmu.2013.00375.

Pinto, C.M.; Ocaña-Mayorga, S.; Lascano, M.S.; Grijalva, M.J. 2006. Infection by trypanosomes in marsupials and rodents associated with human dwellings in Ecuador. Journal Parasitology, 92:1251-1255.

Quaresma, P.F.; Rêgo, F.D.; Botelho, H.A.; da Silva, S.R.; Moura Júnior, A.J.; Teixeira Neto, R.G. et al. 2011. Wild, synanthropic and domestic hosts of Leishmania in an endemic area of cutaneous leishmaniasis in Minas Gerais State, Brazil. Transactions of the Royal Society of Tropical Medicine and Hygiene, 105: 579-585.

Rosa, E.S.; Mills, J.N.; Padula, P.J.; Elkhoury, M.R.; Ksiazek, T.G.; Mendes, W.S. et al. 2005. Newly recognized hantaviruses associated with hantavirus pulmonary syndrome in northern Brazil: partial genetic characterization of viruses and serologic implication of likely reservoirs. Vector Borne Zoonotic Disease, 5:11-19.

Roque, A.L.; Cupolillo, E.; Marchevsky, R.S.; Jansen, A.M. 2010. Thrichomys laurentius (Rodentia; Echimyidae) as a putative reservoir of Leishmania infantum and L. braziliensis: patterns of experimental infection. PLOS Neglected Tropical Diseases, 4(2): e589; doi: 10.1371/journal.pntd.0000589.

Travi, B.L.; Arteaga, L.T.; León, A.P.; Adler, G.H. 2002. Susceptibility of spiny rats (Proechimys semispinosus) to Leishmania (Viannia) panamensis and Leishmania (Leishmania) chagasi. Memórias do Instituto Oswaldo Cruz, 97: 887-892.

Zanini, M.S.; Viana, K.F.; Reis, B.A.; Campos, C.D.; Mussi, J.S.; Zanini, S.F.; Lemos, M.E. 2010. Leishmania (Viannia) braziliensis: immunoblotting analysis for the detection of IgG subclasses in the diagnosis of symptomatic and asymptomatic dogs. Veterinary Parasitology, 173: 143-146.

Recebido em 29/05/2014

Aceito em 16/09/2014 
